\title{
OVINE FAT NECROSIS (FIRST RECORD IN EGYPT)
}

\author{
EL-SEBAIE, A. ${ }^{*}$ and SARY KHALEEL ABD ELGHAFFAR ${ }^{* *}$ \\ * Dept. of Animal Medicine, Faculty of Vet. Med., Assiut University \\ ** Dept. of Pathology Clinical Pathology, Faculty of Vet. Med., Assiut University
}

Email: sebaie@hotmail.com

Assiut University web-site: www.aun.edu.eg

\begin{abstract}
Ovine lipomatosis was observed in a herd of native breed of sheep. The herd was raised in area adjacent to the desert and kept for milk production, while rams used for fattening purpose on the other hand, the herd also used for wool production. The owner paid our attention that the herd showed clinical signs in the form expressed by emaciation, loss of body condition, drop of milk yield from lactating ewes, and reproductive imperformance. Tracing the history of the herd, animals raised and kept on the rest of different typed of maise, wheat and growing grass. While, drinking water was artisan water. Selected cases of the herd were used for further biochemical analysis of some indices reflecting the fat metabolism on the other hand some cases were slaughtered for post-mortem changes. Biochemical indices included total lipids, Triglycerides phospholipids and serum selenium. Postmortem findings showed massive amount of omental adipose tissues with lumpish lesions, and massive fat depot showing lumpish lesion of calcification in mesenteric fat too. Biochemical analysis indicated that there is a marked changes in total lipidis triglycerides, phospholipids and selenium.
\end{abstract}

Received at: $13 / 10 / 2015$

Key words: Ovine, Fat necrosis, lipogram indices

\section{INTRODUCTION}

Abdominal fat necrosis (lipomatosis) is generally characterized by the presence of hard irregular masses of necrotic fat tissue in the mesentery perirenal fat and intestine, a myriad of terms has been applied for this syndrome in duding multiple (Carrol \& Richard, 1958) lipomatus tumour (Edigson, 1952), lipofibromatosis (Moon 1954), Fettgewbsnekrose (Dirksen, 1965) and abdominal necrosis (Williams et al., 1969, El-Sebaie et al., 1985; El-Sebaie and Hofmann, 1992). The above mentioned researches are reffered to bovine fat necrosis but there is no evidence or researches did not mentioned about the occurrence of fat necrosis in small ruminants sheep or goats, whilst the clinical picture of bovine fat necrosis are well recognized, the disease in sheep and goats is for first time diagnosed in sheep herd in Egypt.

\section{MATERIALS and METHODS}

\section{Animals: \\ Sheep herd history:}

A native of 50 local breed of sheep was kept for milk and wall production in a desert area in east bank of Nile of Assiut Governrate where a new cultivated land. Ewes in general were emaciated and varied from 5-7 years old.

\section{Materials: \\ Blood samples}

Blood samples were collected by means of vein puncture, serum samples were separated and used for biochemical essay. Lipogram indices were determined including total lipids, triglycerides, and phospholipids, using Byeunicum spectrophotomer 
and biochemical diagnosis kits. Selenium was measured using Beckmann, plasma Emission.

\section{Tissue Samples:}

Samples of necrotic fat were collected from slaughtered sheep. Tissue samples were taken from the mesenteric and perirenal fat. Samples were fixed in $10 \%$ neutral buffered formalin, dehydrated in different grades of alcohol, embedded in paraffine, sectioned at $45 \mu$, stained with H\&E and examined by light microscopy.

\section{RESULTS}

\section{Clinical Examination:}

Case history indicated that the herd suffered from marked inappetance and decrease in food intake, and milk production as well, further more reproductive disturbance. The herd grazing only on the rest of some wild grass with very little nutrition values, water resources is atrision wells. (Fig. 1, A)

\section{Post mortem findings:}

Some individual of sheep herd slaughtered and post slaughtered examination were carried out, the most post-slaughters findings revealed very chacteristic lesions in some cases, there was accumulation of fat in the mesentery and around, kidneys (Fig. 1, B).
Hard massive amount of omental adipose tissue with lumpish lesions classification and lumpish lesion in mesenteric tissue (Fig. 1, C,D). The presence of well circumscribed irregular areas of necrosis was exident. Some times much more denser than normal, hard, opaque-to grayish-colour and well-demarcated than white zone contaning chalk-like calcification was observed (Fig. 1, D). Advanced stage of fat necrosis revealed the presence of small nodules of necrotic fat in the areas of mesentery. In cut section revealed a dry, hard cheesy opaque appearance.

\section{Histopathology:}

Fat necrosis was markedly seen in the adipose tissue indicated by appearance of feather like crystals. The crystals fill most of the necrotic lipocytes and take the violet colour (Fig.2, a). More there was increase in the amount of interlobular fibrous connective tissue (Fig.2, b). The presence of salty crystals in the lipocytes associated with inter lobular fibrosis give the hard texture of fat indicating advanced of chronic stage of the disease.

\section{Results of biochemical analysis:}

Biochemical analysis of serum revealed marked increase in the mean values of total lipids, triglycerides and phospholipids (Table 1), on the other hand mean values of serum selenium was markedly drop.

Table (1): Mean values of measured parameters in Healtry and diseased sheep ovine fat necrosis

\begin{tabular}{cccccc}
\hline Animals & $\begin{array}{c}\text { Number } \\
\mathbf{n}=\end{array}$ & $\begin{array}{c}\text { Total lipid } \\
\mathbf{g} / \mathbf{L}\end{array}$ & $\begin{array}{c}\text { Tryglcerids } \\
\mathbf{M m o l} / \mathbf{L}\end{array}$ & $\begin{array}{c}\text { Phospholipid } \\
\text { Mmol/L }\end{array}$ & $\begin{array}{c}\text { Selenium } \\
\mathbf{N g} / \mathbf{m l}\end{array}$ \\
\hline Healthy sheep & 10 & 4.61 & 3.48 & 2.02 & 56.9 \\
& S.E & \pm 2.73 & \pm 1.04 & \pm 0.35 & \pm 1.08 \\
\hline Diseased sheep & 8 & 7.44 & 10.57 & 13.38 & 38.40 \\
& S.E & \pm 1.08 & \pm 1.73 & \pm 2.63 & \pm 2.33 \\
\hline
\end{tabular}



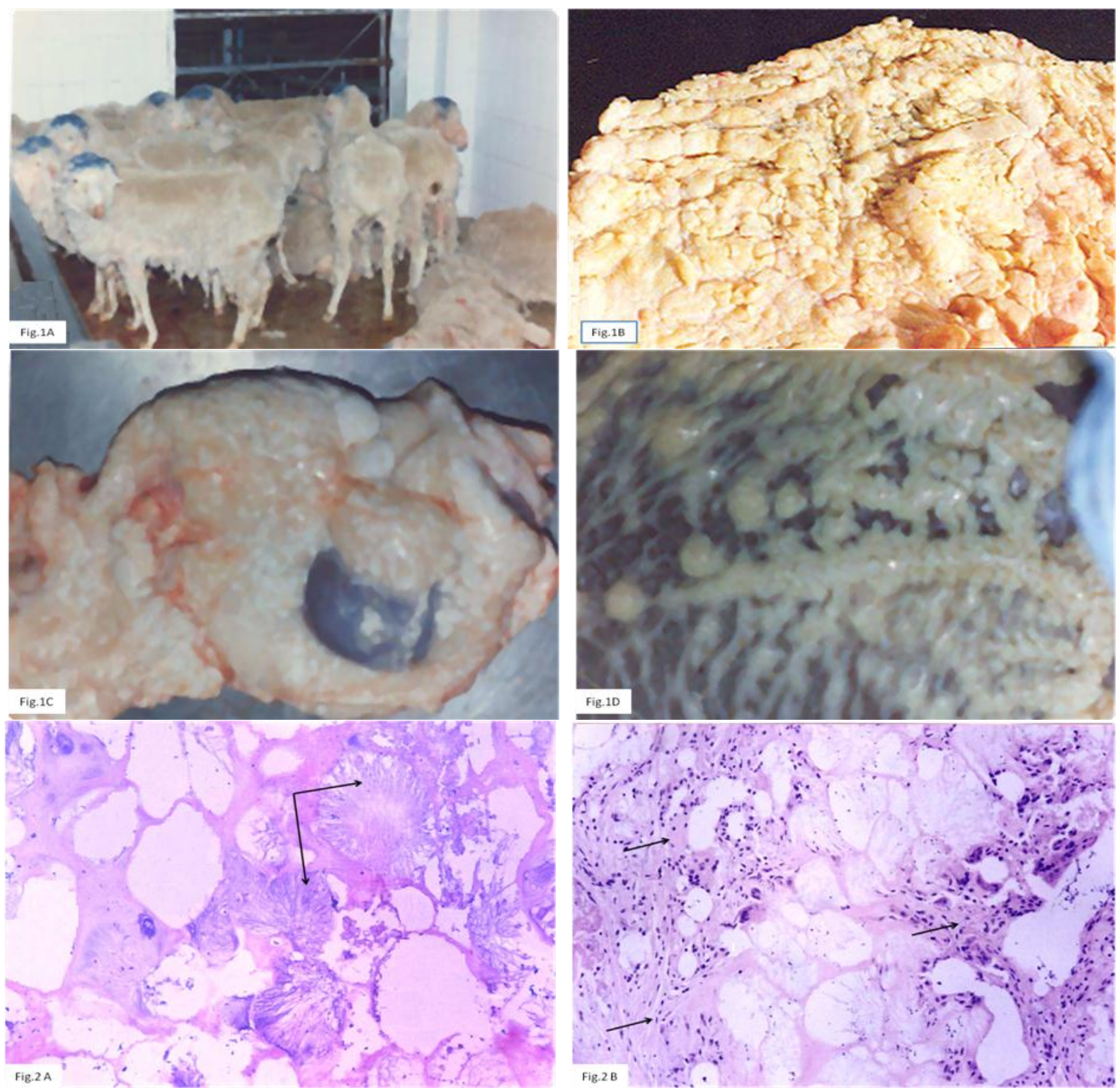

Fig. Legend:

Fig. 1 A: A herd of sheep suffered from fat necrosis (lipomatosis).

B: Hard massive amount of omental adipose tissue with lumpish lesions from the abdominal cavity.

C: Massive amount of prerenal fat showing lumpish lesion and calcification.

D: Calcification and lumpish lesions in the mesenteric tissue.

Fig. 2 A: Adipose tissue section from sheep, showing violet feather like crystals (arrow) fill most of lipocytes (H \& E X 400).

B: Adipose tissue section from sheep, showing increase in the interlobular fibrous connective tissue (arrow) in the lipocytes. H X E X 400.

\section{DISCUSSION}

Ovine fat necrosis as herd problem in sheep herd of local breed in Egypt was reported for the first time, previously studies on bovine fat necrosis as herd problem was reported in Assiut-Egypt (El-Sebaie et al., 1985, El-Sebaie and Hofmann 1988 and Hofmann and El-Sebaie, 1990). Ovine fat necrosis from the clinical signs and post mortem is considered and classified as advanced form if compared with bovine fat necrosis lipomatosis. Tracing the available literature fat necrosis was recorded as individual cases in experimental animals (Adam et al. (1954), and Cox and DeDeds (1958) and Rebelin and Detds (1980).

Further more cases fat necrosis have been mentional is association with selenium deficiency in Horse (Hartley and Dodd, (1957), Dodd et al. (1960); Plattand white well, (1971), Horvath, A.A H.C chany, (1926), Jubb and Kenned, (1970) and Cats (Munscn et al., 1958). Steatosis is in cattle (Fat necrosis 
generally is localized to abdominal fat only (Hartley and Dodd 1957). Maas et al. (1984) have documented a nutritional myodgeneration in Lambs of normal selenium and deficient Vit E.Status. Recent work on native breed cattle in Egypt has suggested the role of selenium deficiency in the pathogenesis of fat necrosis (El-Sebaie and Hofmann (1992)).

\section{CONCLUSION}

Abdominal fat necrosis in general either in Bovine or Ovine fat necrosis may related to dietary factors such as long chain saturated fatty acids consumption selenium deficiency is also to be considered in the pathogenesis of fat necrosis. The lesions develop as an inflammatory response around degenerating adipose cells. The triglycerides within these cells are thought to undergo hydrolysis to glycerol and fatty acids. Remaining clumps or crystals of fatty acids serve as inflammatory foci of subsequent necrosis masses.

\section{REFERENCE}

Carroll, K.K.J.F. Richard (1958): Affecting digestibility of fatty acids in the rat. J. Nutr.64 411-424

Cox, A. and DeEds, F.I. (1958): Dietary production of lipogranulame in rats. Am. J. Path. 34: 263272.

Dirksen, G. (1952): Klinsche beobachtungen uber die fett-gewebsnekrosen beim Rind. Wien. Tierarztl. Monastschr. 55: 517-725.

Dodd, J.C.; Blakely, AA. And Sthornburry, R. (1960): Muscle degeneration and yellow fat disease in foals N.Z.Vet. J. 8, 45-50.

Edgson, F.A. (1952): Bovine lipomatosis. Vet. Rec. 64: 449-454.

El-Sebaie, A.; Hofmann, W. and Bayoumi, A.H. (1987): Lipomatosis with Abdominal fat necrosis in native breed cows in Assiut Egypt.
II-Clinical significance of serum proteins electrophoresis. Assiut Vet. Med.J.18: 198205.

El-Sebaie, A. and Hofmann, W. (1992): Further studies on bovine lipomatosis as Enzootic herd problem. Assiut Vet. Med. 28: 250-266.

El-Sebaie, A. (1993): Clinical investigation on bovine lipomalosis (fat necrosis) as enzootic problem in Al-Hassa Saudi Arabia. 2 $2^{\text {nd }}$. Sci. Cong. Egyption Society for Cattle disease. 34-45.

Hartley, W.J.D. and Dood, C. (1957): Muscular dystrophy in Newzeland liyestockn. Z.N. Vet. J. S, 61-66.

Herting, D.C and Crain, R.C. (1990): Foreign-body type reaction of fat Cattle. Proc. Soc. Exp. Biol. Med. 98, 347-454.

Horvath, A.A. and Chanq, H.C. (1926): The effect of soybean feeding on blood lipose in rabbits. Am. J. Phipiology 78, 224-234.

Jubb, K.V.F. and Kennedy, P.C. (1970): Pathology of domestic Animals 2 $2^{\text {nd }}$ Ed. New York: Academic Press pp. 209-211.

Mass, J.; Bulgin, M.S. and Anderson, B.C. (1984): Nutritional myo degeneration associated with Vet. E deficiency and normal selenium status in Lamb. J. Am. Vet. Med. A ssoc. 184, 201204.

Moon, G.J.H. (1954): Bovine lipomatosis. Newzeland Vet. J. 2: 21-23.

Munson, T.O.; Holzworth, J. and Small, E. (1958): Steatitis (yellow fat) in Cat fed. Canned red Tuna. J. Am. Vet. Med. Ass 133: 563-568.

Platt, H.K. and Whitewell, E. (1971): Clinical and pathological observation on generalized steatis in foal. J. lamp. Path. 81, 494-506.

Wlliams, D.J.; Tyler, D.E. and Popp (1969): Abdominal necrosis as a herd problem in Georgia Cattle. J. Am. Vet. Med. Ass. 154: 1017-1021.

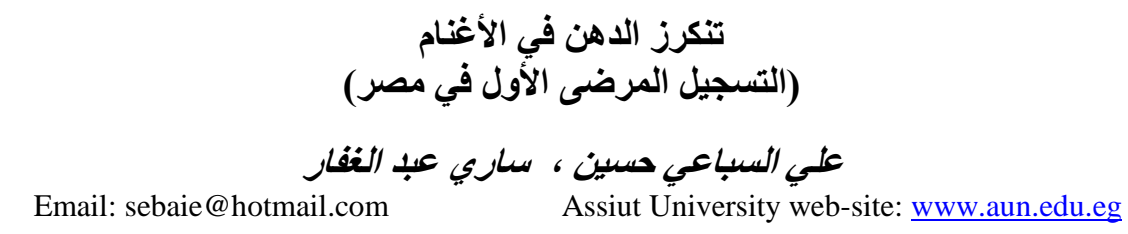

أجريت الدر اسة لأول مره علي الأغنام البلدية - حيث قطيع من الأغنام تربي في الأماكن المستصلحة حديثاً شرق النيل بأسيوطـ كانت

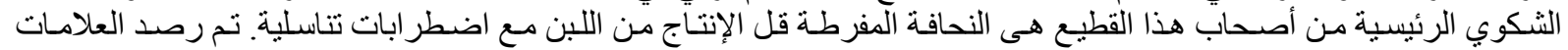

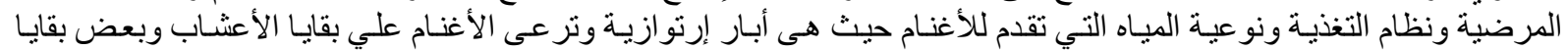

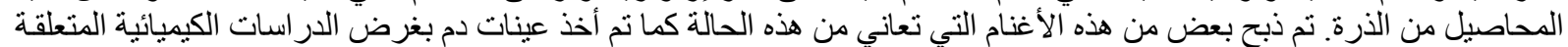

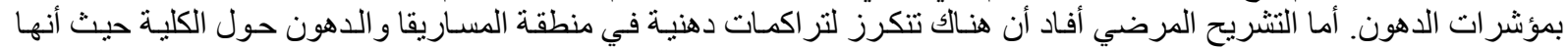

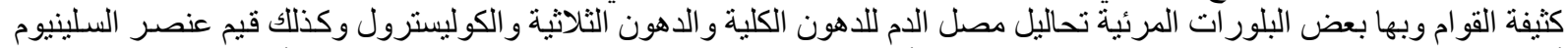

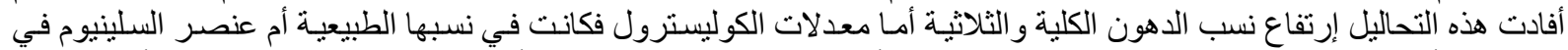

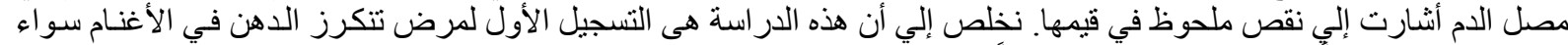

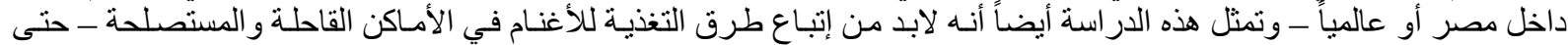

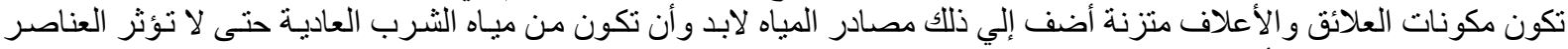
النادرة علي صحة هذه الأغنام. 